\title{
LEGENDA KBO IWA : ASAL-USUL DANAU BATUR DI BALI
}

\author{
Erlis Nur Mujiningsih \\ Badan Pengembangan dan Pembinaan Bahasa, \\ Kementerian Pendidikan dan Kebudayaan, Indonesia \\ E-mail: erlis2006@yahoo.co.id
}

\begin{abstract}
This paperstudies the Bali legend that is the former of Lake Batur. The background story of this legend is the story of Kbo Iwa. Based on the study f Olrix Epic Law, the story of Kbo Iwa is found in all laws except the fifth and sixth i.e. the opposing state law and the legal skeleton of twin brothers. Typically the name "batur" refers to something early and holy related to the source of living water. Geography Lake Batur is associated with Tirta Empul Pool providing the holy water, the largest water source in Bali Island. The sanctity of the lake is marked with the oral tradition of Bhakti Pakelem which obliges local communities to implement a regular basis. The tradition is carried out on the lake and in the mountains to keep the balance of life because the word "batur" in addition to marking the lake is also to mark the mountain and marking Pura Ulun Danu Batur. Thus, the former of the lake cannot be separated from the meaning of the mountain and temple positions. Although, the nature of the legend as other legends does not relate to things that are sanctified, the story of Kbo Iwa can be said to be a rationale importance of the water resources.
\end{abstract}

Keywords: legend; Kbo Iwa; Batur Lake

Abstrak: Tulisan ini mencoba mengakaji legenda di pulau Bali yaitu asal-usul Danau Batur. Kisah yang menjadi latar legenda ini adalah kisah Kbo Iwa. Berdasarkan kajian Hukum Epik Olrix, Kisah Kbo Iwa terdapat semua hukum kecuali hukum kelima dan keenam yakni hukum keadaan yang berlawanan dan hukum anak kembar kerangka. Secara khas nama "batur" mengacu pada sesuatu yang awal dan suci yang berhubungan dengan sumber air kehidupan. Geografi Danau Batur berhubungan dengan pemandian Tirta Empul yang mengeluarkan air suci, sumber air terbesar di pulau Bali. Kesucian danau tersebut ditandai tradisi lisan Bhakti Pakelem yang mewajibkan masyarakat sekitar melaksanakannya secara rutin. Tradisi itu dilaksanakan di danau dan di gunung untuk menjaga keseimbangan kehidupan karena kata "batur" selain untuk menandai danau juga untuk menandai gunung dan menandai Pura Ulun Danu Batur. Dengan demikian, asal usul danau Batur tidak dapat dilepaskan dari pemahaman terhadap posisi gunung dan posisi pura tersebut. Walaupun, sifat legenda sebagaimana legenda lainnya tidak berhubungan dengan hal-hal yang disucikan, kisah Kbo Iwa dapat dikatakan menjadi latar belakang pemikiran pentingnya sumber air.

Kata Kunci : legenda; Kbo Iwa; Danau Batur

Permalink/DOI: http://dx.doi.org/10.15408/dialektika.v2i2.3628 


\section{Pendahuluan}

Nama sebuah wilayah merupakan identitas bagi wilayah tersebut. Sebagai sebuah identitas nama memiliki peranan penting bagi masyarakatnya. Sebagaimana halnya dengan nama diri, nama sebuah wilayah juga merupakan bagian dari alat komunikasi. Dengan adanya nama, sebuah wilayah dikenal oleh masyarakat lain. Bahkan, seringkali terjadi sebuah nama wilayah selain menjadi penanda bagi wilayah tersebut juga menandai penduduk yang menempati wilayah tersebut, misalnya seseorang yang menempati wilayah Jawa akan disebut dengan orang Jawa yang kemudian berefek pada penanda khas kebuduyaan, sejarah, ekonomi, dan bahkan politi. Hal ini menunjukkan bahwa sebuah nama wilayah menjadi begitu penting artinya bagi penduduk yang menempati wilayah tersebut dan juga bagi orang lain yang mengenal penduduk wilayah tersebut.

Nama sebuah wilayah menandai unsur geografi seperti sungai, gunung, dan danau disebut sebagai topografi. Beberapa penelitian tentang nama sebuah wilayah menyimpulkan bahwa penamaan sebuah wilayah seringkali berkaitan dengan legenda ${ }^{2}$ rakyat wilayah setempat dan juga kepercayaan atau agama penduduk yang mendiami wilayah itu. Yang kemudian menjadi persoalan adalah bagaimana hubungan antara nama tersebut dengan legenda yang ada atau dengan kepercayaan yang ada, seberapa penting arti nama tersebut bagi penduduk setempat dan bagi orang-orang yang berada di luar wilayah tersebut.

Tulisan ini mengkaji legenda yang berhubungan dengan terjadinya Danau Batur di Bali. Nama 'Batur" digunakan untuk menandai sebuah wilayah yang terdiri dari gunung, danau, pura, dan desa yang ada di Bagli, Bali. Secara khusus, tulisan ini memfokuskan nama 'Batur' untuk penggunaan nama danau. Salah satu legenda yang berkaitan dengan nama danau Batur adalah legenda Kbo Iwa. Kbo Iwa adalah seorang raksasa yang terkubur air ketika menggali sebuah sumur di daerah Kintamani. Sementara itu, perlu juga disampaikan bahwa kisah Kbo Iwo ini selain beredar di masyarakat sebagai sebuah legenda, juga terdapat di dalam Kakawin Kebo Tanurantaka yang ditulis oleh I Nyoman Singgih Wikarman dan Kakawin Gajah Mada. ${ }^{3}$

\footnotetext{
${ }^{1}$ Oxford Advances Learner's Dictionary, 2000

${ }^{2}$ Menurut Prof. Sapardi Djoko Damono, untuk wilayah Indonesia bukan legenda tetapi dongeng, untuk itu untuk selanjutnya dalam tulisan ini akan digunakan istilah dongeng, Makara UI, 31 Oktober 2012.

${ }^{3}$ I Made Suparta, "Analisis Tokoh Kebo Iwa dalam Kakawin Kebo Tarunantaka" Laporan Penelitian $1994 / 1995$
}

DIALEKTIKA: jurnal bahasa, sastra, dan pendidikan bahasa dan sastra Indonesia, 2(2), 2015 | 195 -215 


\section{Landsan Teori}

Sebagaimana diungkapkan William R. Bascom dalam Danandjaja bahwa cerita prosa rakyat terdiri dari mite, legenda, dan dongeng ${ }^{4}$. Mite sebagaimana disampaikan oleh Bascom adalah cerita rakyat dalam bentuk prosa yang dianggap benar-benar terjadi serta dianggap suci oleh empunya cerita. Mite ditokohkan oleh para dewa atau mahluk setengah dewa. Peristiwa terjadi di dunia lain, atau di dunia yang bukan seperti yang kita kenal sekarang, dan terjadi pada masa lampau. Legenda adalah prosa rakyat yang mempunyai ciriciri yang mirip dengan mite, yaitu dianggap pernah benar-benar terjadi, tetapi tidak dianggap suci. Berlainan dengan mite, legenda ditokohi manusia walaupun ada kalanya mempunyai sifat-sifat luar biasa, dan seringkali juga dibantu mahluk-mahluk ajaib. Tempat terjadinya adalah di dunia seperti yang kita kenal kini, karena waktu terjadinya belum terlalu lampau. Dongeng adalah prosa rakyat yang tidak dianggap benar-benar terjadi oleh empunya cerita dan dongeng tidak terikat oleh waktu maupun tempat ${ }^{5}$.

Berdasarkan pemahaman tentang mite, legenda, dan dongeng tersebut kisah Kbo Iwa sebagaimana dituliskan dalam Margaret Muth Alibasah (1994) ini digolongkan sebagai legenda. Kisah ini dapat digolongkan sebagai legenda karena berkaitan dengan sejarah terjadinya atau terbentuknya Danau Batur. Selain itu, kisah ini tidak berhubungan dengan upacara-upacara atau ritual yang ada di masyarakat. Hal ini berarti kisah ini bersifat sekuler. Tokohnya adalah seorang raksasa yang dikisahkan memiliki kekuatan adikodrati. Kisah ini dapat digolongkan sebagai legenda juga disebabkan adanya penyebutan tempat terjadinya peristiwa yaitu Bali atau secara khusus disebutkan di wilayah Kabupaten Bagli. Secara khusus legenda Kbo Iwa ini dapat digolongkan sebagai legenda setempat karena berkaitan dengan asal-usul terbentuknya sebuah danau di wilayah Kabupaten Bagli. Legenda sebagaimana disebutkan oleh Jan Harold Brunvand dalam Adhyanggono dkk. ${ }^{6}$ dapat dikelompokan menjadi empat yakni legenda keagamaan (religious legends), legenda alam gaib (supernatural legends), legenda perseorangan (personal legends), dan legenda setempat (local legends). Legenda setempat biasanya mengisahkan sejarah suatu tempat, nama tempat tersebut, dan bentuk topografi suatu daerah.

\footnotetext{
${ }^{4}$ R. Bacon dalam James Dananjaya, Folklore Indonesia: Ilmu Gosip, Dongeng, dan lain-lain, (Jakarta: Grafiti, 2007, Cetakan VII) h. 50 .

${ }^{5}$ R. Bacon dalam James Dananjaya, Folklore Indonesia: Ilmu Gosip, ...h. 50.

${ }^{6}$ Jan Harond Brunvand dalam Adyangono dkk., 2005. "Tradisi Cerita Lisan dalam Komunitas Tionghoa di Kawasan Pecinan Kota Semarang” Laporan Penelitian. Semarang: Pusat Studi Urban Universitas Katolik Soegijapranata.
} 
Sebagai sebuah legenda, kisah Kbo Iwa tentunya memiliki hubungan erat dengan pemiliknya, dengan masyarakatnya. Hal tersebut terjadi karena sebuah legenda memiliki apa yang disebut dengan unsur penting. Unsur penting tersebut sebagaimana disampaikan oleh Luthi dalam Sutarto ${ }^{7}$ bahwa legenda dapat digunakan sebagai bukti adanya hubungan antara manusia dengan yang adikodrati. Legenda bertitik tolak dari apa yang terjadi pada manusia, pada halhal yang tidak dipahami yang harus dihadapi oleh manusia. Karena hal-hal yang tidak dapat dipahami itu begitu dahsyat, misalnya perang, wabah, dan tanah longsor dan seringkali semua itu sudah menjadi kehendak Sang Pencipta sehingga membuat manusia menjadi kecil dan tidak berdaya.

Untuk memahami kisah ini dan hubungan antara legenda Kbo Iwa dan nama Batur akan dilakukan analisis terhadap struktur legenda tersebut dengan menggunakan atau mengacu pada hukum-hukum epos (epic laws). Axel Olrix menyatakan struktur atau susunan cerita prosa rakyat terikat oleh hukumhukum yang sama yang disebutnya sebagai hukum-hukum epos. Hukumhukum epos ini merupakan suatu superorganik, sesuatu yang berada di atas cerita-cerita rakyat, yang selalu mengendalikan para juru ceritanya sehingga mereka hanya dapat mematuhi hukum-hukum itu secara membuta. ${ }^{8}$ Olrix dalam Dundes melalui Sudikan mengatakan hukum-hukum itu adalah 1) hukum pembukaan dan penutupan yaitu cerita rakyat tidak akan dimulai dengan suatu aksi tiba-tiba dan juga berakhir secara mendadak; 2) hukum pengulangan, yakni demi pemberian tekanan pada cerita rakyat suatu adegan diulang beberapa kali; 3) hukum tiga kali, yakni tokoh cerita rakyat baru akan berhasil dalam menunaikan tugasnya setelah mencobanya tiga kali; 4) hukum dua tokoh dalam satu adegan, yakni di dalam satu adegan tokoh yang diperkenankan untuk menampilkan diri dalam waktu bersamaan paling banyak hanya boleh dua orang saja; 5) hukum keadaan berlawanan, yakni tokoh-tokoh selalu mempunyai sifat yang berlawanan; 6) kekembaran, anak kembar yang dimaksud di sini dalam arti yang luas karena dapat berarti anak kembar yang sesungguhnya atau saudara kandung, bahkan dua orang yang menampilkan diri dalam peran yang sama; 7) hukum pentingnya tokoh-tokoh yang keluar pertama, dan yang keluar terakhir; 8) hukum satu pokok cerita saja dalam suatu cerita; 9) hukum bentuk berpola cerita rakyat, misalnya seorang pemuda harus pergi ke satu tempat untuk tiga hari berturut-turut dan setiap hari ia akan

${ }^{7}$ Luthi dalam Sutarto, Legenda Kasada dan Karo Orang Tengger Lumajang. (Jakarta : Fakultas Sastra Universitas Indonesia, 1997). h. 25.

${ }^{8}$ Axel Olrix dalam, Setya Yuwana Sudikan. Metode Penelitian Sastra Lisan, Cetakan Kedua. Jakarta : Lamongan: CV Pustaka Ilalang, 2014), h.101. 
bertemu dengan raksasa dan berhasil membunuhnya dengan cara yang sama; 10) hukum penggunaan adegan-adegan tablo yakni adegan-adegan puncak; 11) hukum logika legenda, yakni cerita rakyat mempunyai logikanya sendiri yang tidak sama dengan logika ilmu pengetahuan dan biasanya lebih bersifat animisme berlandaskan pada kepercayaan terhadap kemukzizatan dan ilmu gaib; 12) hukum kesatuan alur, misalnya jika seseorang anak telah dijanjikan diberikan kepada raksasa maka jalan ceritanya berkisar pada masalah bagaimana menghindarkan anak itu dari kekuasaan raksasa itu, dan 13) hukum pemusatan pada tokoh utama.' Sebagaimana disampaikan oleh Sutarto ${ }^{10}$ bahwa hukum epik yang dikemukakan Olrix ini merupakan penelitiannya tentang legendalegenda di Eropa. Oleh karena itu, hukum ini tidak akan dapat diterapkan secara langsung terhadap legenda yang ada di Indonesia, termasuk kisah Kbo Iwa yang akan dianalisis dalam penelitian ini.

\section{Metode Penelitian}

Penelitian ini mengunakan metode kualitatif. Dalam penelitian kualitatif, peneliti mencari makna, pemahaman, pengertian, verstehen tentang suatu fenomena, kejadian, maupun kehidupan manusia dengan terlibat langsung dan/atau tidak langsung dalam setting yang diteliti, kontekstual, dan menyeluruh $^{11}$. Penelitian kualitatif merupakan suatu strategi inquiry yang menekankan pencarian makna, pengertian, konsep, karakteristik, gejala, simbol, maupun deskripsi tentang suatu fenomena; fokus dan multimetode, bersifat alami dan holistik; mengutamakan kualitas, menggunakan beberapa cara, serta disajikan secara naratif. ${ }^{12}$

Metode ini dipilih karena sebagaimana sudah disebutkan yang ingin ditemukan adalah makna kata "batur" dalam hubungannya dengan legenda asalusul danau Batur yang berdasarkan legenda "Kbo Iwa". Memang dalam penelitian kualitatif pencarian makna merupakan ciri utama penelitian kualitatif. Pemahaman terhadap makna tersebut diupayakan dari berbagai macam sudut pandang, pemotretan yang bervariasi, multimetode, dan melalui interaksi simbolik yang merupakan konsep dasar pencarian makna yang sesungguhnya serta mampu memayungi segala bentuk orientasi, menuntun dan

\footnotetext{
${ }^{9}$ Dundes dalam Setya Yuwana Sudikan, Metode Penelitian..., h. 102.

${ }^{10}$ Sutarto, Legenda Kasada dan Karo Orang Tengger Lumajang, (Jakarta : Fakultas Sastra Universitas Indonesia, 1997), h. 18.

${ }^{11}$ Muri Yusyuf, Metode Penelitian Kuantitatif, Kualitatif \& Penelitian Gabungan, (Jakarta : Prenadamedia Group, 2014), h. 328.

${ }^{12}$ Muri Yusyuf, Metode Penelitian..., h. 329.
} 
tidak melebar secara tidak menentu, terfokus walaupun multimetode dan multifokus, terarah dan terkendali. ${ }^{13}$

\section{Pembahasan}

\section{Makna Nama 'Batur'}

Batur sebagaimana sudah disebutkan digunakan untuk nama gunung, nama danau, dan nama desa. Selain itu, 'Batur' juga digunakan untuk nama sebuah pura yang letaknya berada di dalam kawasan tersebut, yaitu Pura Ulun Danu Batur. Kata 'Batur' juga digunakan untuk judul sebuah teks "Sang Hyang Batur Bali" yang ditulis di lontar dan berisi ajaran-ajaran Yoga Kalepasan. Dalam kamus bahasa Bali, dijumpai kata "batur' bermakna 'suci'. Sementara itu, menurut beberapa kamus bahasa Jawa Kuna, kata batur memiliki tiga makna, pertama, batur adalah undak-undakan, atau lantai yang lebih tinggi dari halaman, atau kaki dinding/tembok rumah. Yang kedua, batur berarti sahabat, kawan, abadi, pelayan. Kata "batur" dalam arti yang kedua tidak ditemukan dalam pemakaian bahasa Bali sehari-hari. Yang ketiga, "batur" berarti pertapaan (tempat), dan/atau kepala pertapaan (orang). Kata "batur" juga dapat bermakna undang-undangan menuju spritiual (A.A. Raka Pejeng).

Sementara itu, Made Rijasa dan Wayan Sukada menjelaskan kata "batur" bermakna melihat, menoleh ke timur, dan nandangin/ngulapin di tepi danau dengan tidak puas-puasnya terhadap keindahan alam. Batur juga dapat dimaknai sebagai pusat getaran bumi (Cokorda Kris Puri Ubud). Kata ini juga dapat bermakna "aku yang dipuja" menurut Ida Pedanda Mandara Gria Kusumajati Yang Batu Denpasar. Juga dapat dimaknai sebagai "keluarga kokoh terguh" (Made Titib). Batur juga mengacu kepada sebuah tempat suci sama dengan Besakih.

Selain itu, kata "batur" juga bermakna linggih, gunung, pesimpangan, kawitan, batu etika, juga bermakna asal getaran menuju sonia nol/windu dan pusat buana. Juga dapat bermakna "genah atau ur" yang bermakna tempat di atas (Ida Pedanda Gede Ketut Pidada Geria Punia Sidermen Karangasem). Kata ini juga bermakna "kemoksaan", juga dapat bermakna "pusat perkembangan". Sementara itu, makna kata batur yang berhubungan dengan danau adalah kekuatan alam air yang dipuja sebagai sumber kehidupan (Ida Rai Agung Putra Geria Wangbang Lelateng Jembrana). Makna lain kata "batur" yang berhubungan dengan air adalah sumber air dan amerta (Wayan Kanak,

\footnotetext{
${ }^{13}$ Muri Yusyuf, Metode Penelitian..., h. 330.
} 
Telepud). Kata "batur" ini juga dimaknai sebagai bala batu kekuatan dalam persembahan.

Kata "batur" juga terdapat dalam bahasa Jawa dan Sunda. Dalam bahasa Sunda, kata "batur" berarti teman, orang, atau teman jauh. Sementara dalam bahasa Jawa kata "batur" bermakna pembantu raja. Kata "batur" ini juga ada dalam bahasa Lombok (Sasak) maknanya adalah mitra kerja.

Berbagai makna yang sudah tersebut memperlihatkan bahwa makna kata "batur" dalam bahasa Bali berhubungan dengan hal-hal yang bersifat suci dan secara lebih khusus berhubungan dengan pusat kesucian itu sendiri. Sementara itu, secara khusus dalam hubungannya dengan danau atau air makna kata "batur" adalah sumber air kehidupan. Hal ini menandai pentingnya kata batur dalam kehidupan masyarakat di Bali. Tampaknya hal ini berhubungan dengan pernyataaan bahwa wilayah Batur ini merupakan dasar dan menjadi pusat pemerintahan Bali Mula. ${ }^{14}$

Danau Batur memiliki hubungan ekologis dan mitologis dengan mata air dan pemandian Tirta Empul. Sampai saat ini masih dipercayai bahwa air yang keluar dari mata air tersebut adalah air suci yang apabila dibasuhkan ke wajah akan menjadikan seseorang awet muda. Selain mata air, di tempat itu juga terdapat Pura Tirta Empul dan permandiannya yang terletak di wilayah desa Manukaya, Kecamatan Tampaksiring, Kabupaten Gianyar. Secara ekologis apabila kita melihat peta dengan jelas terlihat adanya jalur aliran sungai di bawah tanah antara Danau Batur dengan mata air Tirta Empul. ${ }^{15}$ Ada kemungkinan di dasar danau ada celah rekahan sehingga air danau mengalir di bawah tanah yang kemudian menyembur ke luar di Manukaya menjadi sebuah mata air. Mata air Tirta Empul merupakan semburan yang terbesar di kawasan Bali Selatan. Rembesan air Danau Batur berupa mata air juga ditemukan di Bali Utara, misalnya di dekat Pura Ponjok Batu, Yeh Sanih, Bukti, Bondalem, dan Tejakula. Sesuai dengan tatanan adat dan agama di zaman Bali Kuna, Kerajaan Bedahulu memiliki tiga buah pura utama, yaitu: Pura Gunung, Pura Penataran, dan Pura Segara. Sebagai Pura Gunung ditetapkanlah telaga ini yang kemudian dinamakan Pura Tirta Empul. Sebagai Pura Penataran dibangun Pura Samuan Tiga, karena letaknya dekat Istana Bedahulu. Pura Tirta Empul menjadi tempat suci stana Bhatara Indra. Selanjutnya Bhatara Indra diyakini telah menciptakan tirta-tirta, yakni 1) Tirta Tegteg, 2) Tirta Sudamala, 3) Tirta Panglukatan, 4)

\footnotetext{
${ }^{14}$ Wayan Sukadia, Karya Agung Tawur Agung Labuh Gentum, Mendak Toya, Tur Pakelem Ring Segara Danu Lan Gunung Batur (Danu Kerthi), (Desa Pekraman Batur: Segara Danu Pura Jati, 2009), h. iv

${ }^{15}$ Koneksitas Danau Batur Tirta Empul” http: / / stitidharma.org/koneksitas-danau-batur-tirta-empul
} 
Tirta Pamarisuda, 5) Tirta Pamlaspas, 6) Tirta Panglebur Ipian Ala, 7) Tirta Pangentas, 8) Tirta Pabersihan.

Tirta-tirta itu dialirkan melalui pancuran sehingga warga yang datang untuk metirta yatra dan mensucikan diri, dapat memilih pancuran tertentu sesuai dengan permohonan mereka kepada Bhatara Indra. Mata air besar ini mengalir ke Tukad Pakerisan dan Tukad Patanu. Cerita Tirta Empul ada dalam Lontar Usana Bali dalam bentuk kekawin yang dinamakan Mayadanawantaka. Dalam Purana Tattwa Batur di bagian Raja Purana Pura Ulun Danu Batur, disebutkan bahwa Bhatari Dewi Danuh yang beristana di Danau Batur "bersaudara" dengan Bhatara Indra yang berstana di Tirta Empul. Dengan demikian, apabila dilihat dari sudut mitologis kata 'Batur' yang bermakna suci memiliki hubungan dengan mata air Tirta Empul yang maknanya juga adalah 'air suci', yang menjadi bagian tidak terpisahkan dari tataran adat dan agama di Bali. Dengan demikian, kata 'batur' yang menunjuk kepada danau, gunung, dan desa berasosiasi kepada induk atau yang disucikan. Oleh sebab itu, di wilayah Batur masyarakatnya tidak diperbolehkan memelihara kuda dan sapi. Karena kotoran binatang-binatang tersebut akan mengotori air yang disucikan dari mata air yang ada.

\section{Asal Usul Nama}

Asal usul kata 'Batur' berhubungan dengan nama gunung yaitu Gunung Batur. Gunung Batur merupakan sebagian puncak Gunung Mahameru yang dipindahkan oleh Bhatara Pasupati (Siwa) untuk istana Dewi Danu yang dipindahkan dengan tangan kirinya, sementara sebagian puncak lainnya dipindahkan dengan tangan kanannya untuk istana Dewa Putranjaya.

Gunung Agung maknanya adalah gunung yang besar dan tinggi adalah laki-laki. Gunung Batur adalah gunung suci adalah perempuan. Kedua gunung ini adalah lambang laki-laki (purasa) dan lambang perempuan (pradana) untuk ulu (kepala) pulau Bali. Di kedua gunung ini masing-masing juga terdapat dua pura, yaitu Pura Besakih yang terletak di Gunung Agung dan Pura Batur yang ada di Gunung Batur. Di Pura Besakih, Tuhan dipuja untuk menguatkan jiwa kerohanian umat untuk mencapai kebahagiaan spiritual. Sedangkan di Pura Batur, Tuhan dipuja untuk menguatkan spiritual umat dalam membangun kemakmuran ekonomi. Oleh sebab itu, di Gunung Batur selain gunung juga terdapat danau. Di dalam masyarakat Bali, danau memiliki dewanya tersendiri yakni Dewa Danu (Dewa Air Danau) yang melambangkan kemakmuran dan kesuburan. 


\section{Geografi}

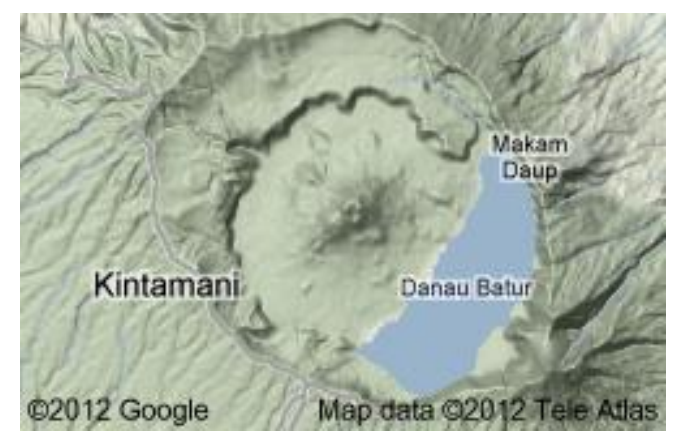

Gambar 1. Foto Kaldera Gunung Batur

Danau Batur adalah sebuah danau yang terletak di Kabupaten Bagli. Tepatnya pada 115,29 bujur timur dan 8,28 lintang selatan dengan luas $6 \mathrm{~km}^{2}$ yang merupakan lembah dari Gunung Batur. Danau ini merupakan danau terbesar di Pulau Bali. Tiga danau lainnya adalah Tamblingan, Bulian (Buyan), dan Beratan. Desa-Desa yang ada di sekitar danau adalah Songan, Trunyan, Abang, Buahan, Kedisan, dan Toya Bungkah.

Nama Batur di wilayah ini tidak hanya untuk menandai danau, tetapi juga untuk menandai gunung, desa, dan pura. Antara gunung dan danau terdapat ikatan yang sangat erat. Danau Batur dan Gunung Batur merupakan satu kesatuan alam dan mitologi yang tidak dapat dipisahkan. Secara geologis antara Danau dan Gunung Batur juga tidak dapat dipisahkan. Danau Batur terbentuk akibat letusan yang terjadi sekitar 29.300 tahun yang lalu, diawali dengan muntahan 84 kilometer kubik ignimbrite (material vulkanik). Letusan dahsyat ini membentuk kaldera Batur pertama. Letusan besar kedua terjadi 20.150 tahun lalu dan memuntahkan $19 \mathrm{~km} 3$ ignimbrit dan membentuk kaldera kedua. Di dasar kaldera kedua ini kemudian tumbuh Gunung Api Batur.

\section{Mata Pencaharian}

Mata pencaharian Masyarakat di sekitar Danau Batur adalah sebagai nelayan. Ikan yang mereka budi dayakan adalah ikan nila. Potensi ikan nila tercatat 1.765 ton (jaring apung dan budidaya), ikan mas sekitar 37,5 ton, dan lele 0,3 ton (hasil sensus tahun 2011, BPS Kabupaten Bagli). Daerah ini juga penghasil bawang merah, bawang putih, dan cabai. ${ }^{16}$

16 “Kami Penjaga Alam Danah Batur” http:/ / tanahair.kompas.com/read/2012/09/18/1656278/Kami. Penjaga.Alam.Danau.Batur

202-215 | DIALEKTIKA: jurnal bahasa, sastra, dan pendidikan bahasa dan sastra Indonesia, 2(2), 2015 
Selain itu, sebagaimana daerah Bali lainnya danau Batur juga menjadi tempat wisata. Danau Batur sendiri sebagai salah satu danau terbesar di pulau Bali memiliki peran penting dalam tradisi subak. Pura Batur juga ditenggarai sebagai salah satu pura yang menjadi sentra subak. Dengan adanya tradisi ini, ditenggarai bahwa peran air menjadi sangat penting bagi masyarakat Bali. Dengan demikian, juga menandai peran penting danau Batur sebagai sumber untuk mengelola mata pencaharian penduduknya yaitu pertanian. Secara khusus subak dimaknai sebagai cara pengelolaan air untuk persawahan yang terkait erat dengan budaya dan sistem kepercayaan masyarakat yang mencerminkan keharmonisan antara alam dan manusia, manusia dan manusia, dan manusia dan penciptanya melalui filosofi Tri Hita Karana. Melalui tradisi subak ini kualitas air terjaga dengan baik. "Subak dari Bali ditetapkan sebagai warisan dunia" dalam. ${ }^{17}$ Uraian tersebut dapat diperlihatkan bahwa air dalam masyarakat Bali memiliki peran yang sangat penting.

\section{Kepercayaan/Agama}

Kata 'Batur' adalah juga nama untuk sebuah pura yaitu Pura Ulun Danu Batur. Pemakaian nama 'Batur' sebagai nama pura tersebut nampaknya menandai bahwa kata tersebut sangat erat hubungannya dengan persoalan kepercayaan dan agama yang dianut oleh masyarakatnya. Hal ini juga berhubungan erat dengan makna kata'batur' itu sendiri yang memiliki makna 'suci' dan kemudian karena danau merupakan sumber air kata 'suci' dapat dihubungkan dengan keberadaan 'air suci'. Air ini sebagaimana sudah disampaikan sebelumnya keluar bukan di danau Batur, tetapi keluar sebagai mata air di Pura Tirta Empul yang terletak di Tampak Siring. Namun, sebagaimana juga sudah diungkapkan bahwa menurut data ekologis antara danau Batur dan mata air di pura tersebut terdapat aliran sungai bawah tanah yang menandai bahwa air dari danau Batur mengalir ke mata air tersebut. Air suci yang ada di Pura Tirta Empul ini oleh masyarakat Hindu sebagai tempat untuk memurnikan fisik dan spritual atau menurut tradisi lokal dikenali sebagai tradisi 'melukat'. Air ini juga dipercaya memiliki kekuatan magis. ${ }^{18}$ "Sebagai sebuah nama pura kata 'Batur' juga memiliki peran yang amat penting bagi kepercayan masyarakat Hindu terutama bagi masyarakat Bali itu sendiri. Peran Pura Ulun Danu Batur yang merupakan pusat pemujaan bagi dewi Danu atau

\footnotetext{
17 “Subak Bali Ditetapkan Sebagai Warisan Dunia”, http://m.nationalgeographic.co.id/berita/2012 /06/subak-dari-bali-ditetapkan-sebagai-warisan-dunia, diunduh 7 Maret 2013.

${ }^{18}$ Mata Air Suci di Pura Tirta Empul” dalam http://id.balibalibeach.com/pura/pura-tirta-empul-mata-airsuci/feed/, diunduh 7 Maret 201.
} 
dewi kesuburan yang kalau dihubungkan dengan Gunung Agung yang dipercaya masyarakat Bali sebagai gunung laki-laki, sementara gunung Batur dipercaya sebagai gunung perempuan dan menandai kesuburan. Kata 'batur' memiliki makna yang mengacu kepada persoalan bahwa gunung Batur dan gunung Agung merupakan sepasang gunung yang mengibaratkan dan dipercaya oleh masyarakat Bali sebagai sepasang laki-laki dan perempuan yang dipercaya sebagai 'ulu' atau yang berkuasa di pulau tersebut. Gunung Batur sebagai gunung yang dipercaya sebagai gunung perempuan secara khusus ditandai berbeda dengan Gunung Agung. Hal ini disebabkan adanya danau Batur. Sebagai gunung perempuan, gunung Batur dengan danaunya memiliki peran yang besar bagi kemakmuran masyarakat Bali. Di sini terlihat bagaimana peran air yang merupakan hal yang utama bagi berlangsungnya kehidupan manusia, terutama apabila dihubungkan dengan mata pencaharian penduduk Bali pada masa lampau yang menggantungkan hidup mereka pada pertanian. Hal tersebut terlihat jelas dengan adanya tradisi 'subak' atau pengaturan irigasi bagi persawahan yang sudah ada sejak masa lampau.

\section{Legenda}

Legenda yang sering disebut dengan danau Batur adalah cerita rakyat yang berjudul "Kebo Iwa" atau "Kbo Iwo". Kisah ini berdasarkan data yang ada terdiri dari dua versi yakni versi yang berhubungan dengan terjadinya danau Batur dan versi yang berhubungan dengan Majapahit. Untuk keperluan analisis ini yang akan digunakan adalah versi yang berkaitan dengan terjadinya Danau Batur, namun versi yang berhubungan dengan Majapahit juga akan disinggung karena versi ini memberikan gambaran mengenai ketokohan Kebo Iwa. Bahkan secara khusus Kabupaten Gianjar menjadikan tokoh Kebo Iwa sebagai ikon kabupaten tersebut dengan berdasarkan SK Bupati Gianyar Nomor 901/05H/HK/2012. Berikut adalah foto patung Kebo Iwa yang ada di Kabupaten Gianyar.

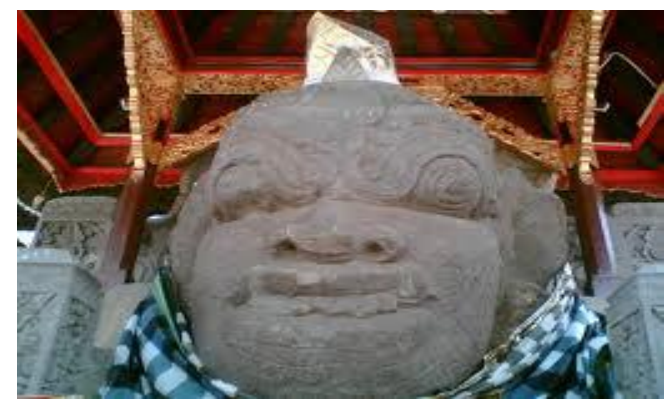

Gambar 2. Patung Kebo Iwa di Pura Gaduh di Kabupaten Gianyar 
Dalam versi yang berkaitan dengan Majapahit tokoh Kbo Iwa merupakan pahlawan yang dihormati karena dia adalah patih dari raja Bali Kuna yaitu raja Sri Tapolung dengan gelar Sri Asta Sura Ratna ${ }^{19}$ yang mempertahankan Bali dari serangan Majapahit.

Dikisahkan sebagaimana tercantum dalam Kakawin Kebo Tarunantaka karya I Nyoman Singgih Wikarman, Kbo Iwa adalah seorang patih yang sangat sakti dan kebal oleh senjata tajam. Hal ini yang membuat Majapahit, secara khusus, patih Gajah Mada merasa terancam dan membuat siasat untuk menaklukkan Kbo Iwa. Versi kedua yang berkaitan dengan Majapahit ini tidak menyinggung sama sekali mengenai terjadinya Danau Batur.

Berdasarkan laporan penelitian "Analisis Tokoh Kebo Iwa dalam Kakawin Kebo Tarunantaka” kisah mengenai Kbo Iwa dibaginya dalam tiga versi yaitu yang pertama ada di dalam Kakawin Kebo Tarunantaka, versi kedua adalah versi yang ada Kakawin Gadjah Mada, versi ketiga adalah versi yang disebutnya sebagai versi cerita rakyat Bali. ${ }^{20}$ Versi pertama dan versi kedua tampaknya dapat disatukan karena versi ini adalah versi yang berkaitan dengan Majapahit, sementara versi ketiga adalah versi yang berkaitan dengan asal usul terjadinya Danau Batur. Kedua versi tersebut ada dan dimiliki oleh masyarakat Bali pada saat ini. Sebagaimana yang sudah penulis lakukan melalui wawancara dengan salah seorang warga Denpasar yang mengetahui kisah Kbo Iwa versi yang berkaitan dengan Majapahit ${ }^{21}$.

Kbo Iwa berdasarkan cerita rakyat, adalah anak sepasang suami istri kaya raya. Karena Kbo Iwa memerlukan makanan yang banyak, harta kedua orang tuanya pun habis. Warga desa pun kemudian memberi makan Kbo Iwa, tetapi karena memang Kbo Iwa membutuhkan makanan yang banyak penduduk desa juga tidak mampu lagi memberinya makan. Pada musim kemarau persediaan makanan di desa itu sudah habis. Kbo Iwo marah karena tidak mendapatkan makanan. Dia begitu marah dan merusak berbagai bangunan di sekitarnya.

Masyarakat desa kemudian membangun kembali bendungan, rumahrumah, dan pura yang sudah dirusak oleh Kbo Iwa dengan mengumpulkan batu kapur. Kbo Iwa yang sedang menggali waduk untuk irigasi bertanya-tanya mengapa penduduk mengumpulkan kapur sangat banyak. Penduduk menjawab

\footnotetext{
${ }^{19}$ I Made Suparta. "Analisis Tokoh Kebo Iwa dalam Kakawin Kebo Tarunantaka”. Laporan Penelitian. Jakarta: Fakultas Sastra Universitas Indonesia, 1994/1995. h.10.

${ }^{20}$ I Made Suparta. “Analisis Tokoh Kebo Iwa dalam Kakawin Kebo Tarunantaka”. Laporan Penelitian. Jakarta: Fakultas Sastra Universitas Indonesia, 1994/1995. h.10.

${ }^{21}$ Wawancara dengan Ni Luh Ani sebagai pencerita versi yang berkaitan dengan , 26 Februari 2015
} 
untuk membuatkan rumah bagi Kbo Iwa. Selama ini Kbo Iwo tidur di sembarang tempat. Ia tentu saja senang mendengarnya, sehingga bekerja semakin dalam. Setelah selesai istirahat dan makan, Kbo Iwa kembali bekerja. Setelah itu Kbo Iwa tidur di dalam sumur yang sedang digalinya.

Seminggu lamanya Kbo Iwa tidak muncul, ternyata ia tertidur panjang di dalam sumur yang digalinya. Penduduk mulai melempari kapur ke dalam lubang yang digali. Kapur itu bercampur dengan air dan menyebabkan Kbo Iwa tewas. Air tersebut kemudian meluap dan menjadi Danau Batur. Hal tersebut seperti yang tercantum dalam kisah Kbo Iwa di buku Folk Tales from Bali and Lombok karya Margaret Muth Alibasah sebagaimana tercantum berikut ini:

After he had finished eating, Kbo Iwa descended deep into the earth again, to continue his work. As a matter of fact, he did not work, but laid himself down to sleep after his huge meal. For several days he did not reappear on the surface, and the people standing on the edge of the well could not see him at all. They began to wonder what had happened to him. Was he still working? Or was he burried under the earth that he had been digging?

Suddenly there was a sound as of thunder. It was a fine day, with no sign of a storm coming up, so the people knew that Kbo Iwa was in a deep sleep, and because of the size and depth of the well, the sound of his snoring reverberated far and wide.

This was the moment the village chief had been waiting for. As soon as he gave them the predetermined sign, the people began pouring lime into the well. As they did so, water began to rise from the earth deep below them, and Kbo Iwa floated on top, still fast asleep, unaware of what was happening. ${ }^{22}$

Dari berbagai cerita yang dikisahkan oleh masyarakat, ada beberapa hal yang dapat dikatakan menjadi ciri khas kisah Kbo Iwa ini. Yang pertama adalah tokoh utamanya yaitu Kbo Iwa memiliki badan tinggi besar. Beberapa kisah menyebutnya sebagai seorang raksasa, kisah-kisah lainnya menyebutkannya sebagai manusia tetapi tinggi besar seperti raksasa. Persamaan berikutnya adalah sang tokoh memerlukan makanan yang banyak sehingga penduduk kewalahan untuk memenuhinya. Hal berikutnya adalah tokoh ini digambarkan memiliki sifat baik penolong dan pembangun waduk, rumah, dan pura. Juga disebutkan bahwa tokoh Kbo Iwa ini sangat sakti dan memiliki keahlian mendatangkan air. Beberapa kisah disampaikan bahwa dengan hanya menancapkan telunjuknya ke

${ }^{22}$ Margaret Muth Alibasah, "Kbo Iwa" dalam Folk Tales from Bali and Lombok, (Jakarta : Djambatan, 1994), h. 27-28. 
tanah akan keluar sumber air, ada yang mengatakan dengan menapakkan kakinya yang besar juga akan keluar air.

Yang menarik dan tampaknya ini yang akan menghubungkan kisah ini dengan asal usul Danau Batur adalah ciri yang disebutkan terakhir bahwa tokoh Kbo Iwa adalah seseorang yang dapat memunculkan mata air. Dia adalah seorang pembuat sumur. Bagi masyarakat Bali, air merupakan hal utama. Selain dipergunakan untuk keperluan sehari-hari, sebagaimana sudah disebutkan sebelumnya bahwa Danau Batur ini berhubungan dengan air suci di Kintamani maknanya adalah bahwa air merupakan salah satu unsur penting dalam peribadatan masyarakat Hindu.

Hal berikutnya yang perlu juga disinggung di sini adalah hilangnya kesaktian Kbo Iwa karena dilempari air kapur. Adanya syarat kapur untuk dapat mengalahkan musuhnya ada di dalam tiga versi kisah Kbo Iwa. Hal ini menandai bahwa kapur menjadi barang yang sangat berharga bagi tokoh Kbo Iwa.

Selanjutnya, kisah Kbo Iwa akan dianalisis berdasarkan hukum Olrix. Hukum yang pertama adalah hukum pembukaan dan penutup, yakni sebuah cerita rakyat tidak akan dimulai dengan suatu aksi tiba-tiba, dan tidak juga berakhir dengan mendadak. Pada kisah Kbo Iwa cerita dimulai dengan memperkenalkan terlebih dahulu orang tua Kbo Iwa dan bagaimana cara mereka mendapatkan Kbo Iwa sampai kemudian mereka memperoleh anak dengan keistimewaan, yakni suka sekali makan. Hal ini menandai bahwa kisah ini tidak muncul secara tiba-tiba. Akhir kisah ini juga tidak muncul secara tibatiba.

Kisah Kbo Iwa diakhiri dengan kematian Kbo Iwa di dalam sumur yang digalinya yang kemudian menjadi Danau Batur dan Gunung Batur. Kematian Kbo Iwa digambarkan karena terjadinya musim kemarau sehingga bahan makanan berkurang. Kbo Iwa yang berbadan besar memerlukan makanan yang banyak. Saat kemarau datang, penduduk tidak dapat lagi menyediakan makanan untuknya. Hal ini memicu kemarahan sang tokoh sehingga dia merusak semua yang sudah dibangunnya.

Tentu saja perbuatan Kbo Iwa ini menakutkan masyarakat. Oleh sebab itu, masyarakat mencari jalan bagaimana mengatasi keganasan Kbo Iwa. Kemudian muncul ide untuk mencelakakan Kbo Iwa. Saat Kbo Iwa tidur lelap setelah selesai bekerja dia dilempari kapur sehingga menyebabkan ia tewas. Kapur merupakan kata kunci yang selalu ada dalam cerita Kbo Iwa baik versi 
yang berkaitan dengan terjadinya Danau Batur maupun versi yang berkaitan dengan Majapahit. Kapur merupakan kunci kelemahan kesaktian Kbo Iwa. Hal yang serupa juga muncul dalam versi yang berkaitan dengan Majapahit sebagaimana dikutipkan berikut.

Patih Gajah Mada memerintahkan Kebo Iwa untuk membuat sumur yang sangat dalam. Ketika Kebo Iwa sedang berada di dalam sumur, patih memerintahkan pengawalnya untuk menimbun sumur, patih memerintahkan pengawalnya untuk menimbun sumur itu dengan kapur. Kapur itu menyebabkan Kebo Iwa sesak napas. Ia pun tewas di dalam sumur. ${ }^{23}$

Dari uraian tersebut, diuraikan bahwa hukum epik Olrix yang pertama yaitu hukum pembukaan dan penutup ada di dalam kisah ini. Hukum berikutnya adalah hukum pengulangan yakni demi pemberian tekanan pada cerita rakyat suatu adegan diulang beberapa kali. Pengulangan yang tampak pada kisah Kbo Iwa adalah pengulangan dalam hal bagaimana sang tokoh makan, yakni dimulai ketika Kbo Iwa lahir orang tuanya dalam kondisi kaya raya. Mereka kehabisan harta bendanya karena harus memberi makan kepada Kbo Iwa. Berikutnya adalah penduduk desa yang harus memberi makan kepada Kbo Iwa. Akhirnya, penduduk juga kehabisan makanan saat musim kemarau datang. Pengulangan peristiwa pemberian makanan kepada Kbo Iwa dan yang kemudian menyebabkan orang-orang tersebut kehabisan bahan makanannya merupakan hukum Olrix yang kedua. Pengulangan peristiwa ini juga merupakan pemicu terhadap proses penyelesaian cerita.

Hukum Olrix berikutnya adalah hukum tiga kali yakni tokoh cerita rakyat baru akan berhasil dalam menunaikan tugasnya setelah mencobanya tiga kali. Kisah Kbo Iwa tidak memunculkan pahlawan sebagai tokoh utamanya. Kbo Iwa walaupun diberi sifat baik hati dan penolong, tetapi karena dia harus makan dalam jumlah banyak menyebabkan tokoh ini harus disingkirkan. Oleh sebab itu, pada kisah Kbo Iwa ini tidak muncul wira yang mencoba mencapai tujuan. Hukum tiga kali tampak dalam kisah Kbo Iwa melalui pemenuhan kebutuhan makanan bagi sang tokoh. Yang pertama adalah orang tuanya. Orang tua Kbo Iwa adalah seorang yang kaya raya sehingga mereka dapat memenuhi kebutuhan makanan bagi anaknya. Setelah orang tuanya yang kedua adalah penduduk desa, ketika orang tuanya sudah tidak sanggup penduduk desa memenuhi kebutuhan makanan Kbo Iwa. Akhirnya, penduduk desa juga tidak sanggup memenuhi kebutuhan makanan Kbo Iwa. Yang terakhir atau yang ketiga adalah kondisi

${ }^{23}$ Sekar Septiadari, "Kebo Iwa" dalam Seri Cerita Rakyat Bali, (Jakarta : Karisma Publishing Group, 20100), h. 17.

208-215 | DIALEKTIKA: jurnal bahasa, sastra, dan pendidikan bahasa dan sastra Indonesia, 2(2), 2015 
alam yakni datangnya musim kemarau yang menyebabkan persediaan makanan habis. Yang ketiga inilah yang menyebabkan penduduk desa berpikir untuk melenyapkan Kbo Iwa.

Hukum keempat adalah hukum dua tokoh dalam satu adegan. Dakam satu adegan cerita rakyat, tokoh yang diperkenankan untuk menampilkan diri dalam waktu bersamaan, paling banyak boleh dua orang saja. Kisah Kbo Iwa menampilkan tokoh sepasang suami istri, tokoh Kbo Iwa, dan penduduk yang mendiami desa. Setiap adegan yang ditampilkan memang hanya muncul dua tokoh saja, misalnya saat suami istri ingin memiliki anak yang muncul adalah dua tokoh itu saja yaitu suami dan istri. Selanjutnya saat Kbo Iwa konflik dengan penduduk desa. Walaupun penduduk desa itu jumlahnya sangat banyak, tetapi memiliki sikap dan perilaku yang sama artinya penduduk desa tersebut dapat dianggap sebagai satu orang saja. Hal ini menandai bahwa memang dalam sebuah cerita rakyat tokoh-tokohnya muncul dalam bentuk yang sederhana. Hukum dua tokoh dalam satu adegan berlaku dalam kisah ini.

Hukum berikutnya adalah hukum keadaan berlawanan, yakni tokohtokoh cerita rakyat selalu mempunyai sifat yang berlawanan. Tokoh Kbo Iwa sendiri di dalam dirinya memiliki sifat yang berlawanan. Dia baik hati dan penolong, tetapi karena dia memerlukan makanan yang banyak Kbo Iwa menjadi pemarah. Hanya memang sifat pemarah Kbo Iwa tersebut dipicu rasa laparnya. Tokoh dalam kisah ini tidak terlalu banyak dan sifat yang berlawanan tidak dimunculkan dalam kisah ini. Hukum ini tampaknya tidak muncul.

Hukum keenam adalah hukum anak kembar. Yang dimaksudkan anak kembar di sini mempunyai arti yang luas karena dapat berarti anak kembar sesungguhnya atau dua saudara kandung, bahkan dua orang yang menampilkan diri dalam peran yang sama. Kisah Kbo Iwa tidak memunculkan hukum ini. Kekembaran tidak hadir.

Hukum ketujuh adalah hukum pentingnya tokoh-tokoh yang keluar pertama dan yang keluar terakhir. Kisah Kbo Iwa ditokohi oleh sepasang suami istri, Kbo Iwa, dan penduduk desa. Tokoh Kbo Iwa dari awal sudah muncul sampai di akhir cerita. Tokoh ini merupakan tokoh utama yang menjadi pusat cerita. Walaupun tokoh ini bukanlah seorang wira (dalam versi asal usul danau, bukan wira tetapi pada kisah yang berkaitan dengan Majapahit tokoh Kbo Iwa adalah wira), tetapi tokoh inilah yang menjadi pusat perhatian cerita. Tokoh ini menjadi penting dari awal sampai akhir cerita. Apa pun adegan yang dimunculkan dalam kisah Kbo Iwa adalah untuk mengisahkan tokoh tersebut. 
Hukum ini berlaku dengan tokoh Kbo Iwa sebagai pelakunya. Hal ini mendukung pemahaman bahwa cerita rakyat memiliki tokoh cerita yang sederhana sebagaimana berlaku pada hukum yang keempat.

Hukum kedelapan adalah hukum ada satu pokok cerita saja dalam suatu cerita yakni dalam satu cerita jalan ceritanya tidak akan kembali lagi hanya untuk mengisi kekurangan yang tertinggal. Pada kisah Kbo Iwa memang hanya ada satu pokok cerita saja yaitu bagaimana penduduk desa menyelematkan desanya dari kemarahan sang tokoh akibat sang tokoh tidak mendapatkan bahan makanan yang memadai. Kisah yang berkaitan dengan asal terjadinya Danau Batur ini memang terkesan sangat sederhana. Sedikit berbeda dengan kisah Kbo Iwa yang berkaitan dengan Majapahit. Pada versi ini pokok cerita berkembang ke arah konfilk antaran kerajaan Bali Kuna dengan Majapahit juga di dalamnya ada kemauan patih Gadjah Mada untuk menyatukan Nusantara.

Hukum kesembilan adalah hukum bentuk berpola cerita rakyat. Pola cerita rakyat yang ada di dalam kisah Kbo Iwa adalah Kbo Iwa merupakan seorang tokoh yang sakti dengan hanya menusukkan jarinya ke tanah dia akan mendapatkan air. Berkali-kali Kbo Iwa melakukan hal tersebut sehingga penduduk desa dapat memiliki sumur. Apa yang dilakukan oleh Kbo Iwa dilaksanakannya secara berulang-ulang. Hal ini menunjukkan adanya pola tertentu pada kisah ini yang berhubungan dengan sumber air sehingga kisah ini dapat dihubungkan dengan asal usul terjadinya danau Batur.

Hukum kesepuluh yakni hukum penggunaan adegan-adegan tablo. Pada kisah Kbo Iwa adegan puncak terjadi ketika orang tua Kbo Iwa tidak sanggup lagi memberikan makan kepada Kbo Iwa, berulang lagi ketika penduduk desa tidak dapat memberi makan kepada Kbo Iwa, adegan puncak muncul kembali ketika Kbo Iwa akhirnya mati dilempari kapur saat dia tertidur di dalam galian sumurnya.

Hukum kesebelas adalah hukum logika legenda yakni cerita rakyat mempunyai logikanya sendiri yang tidak sama dengan logika ilmu pengetahuan. Hal ini segera dapat terlihat dalam kisah Kbo Iwa. Bahwa terjadinya danau Batur bukan disebabkan oleh letusan gunung Batur, tetapi karena kesaktian Kbo Iwa yang dengan hanya menancapkan telunjuk jarinya ke tanah akan keluar air dan yang kemudian menjadi danau. Ini adalah logika legenda. Kehadiran Kbo Iwa yang tinggi besar seperti raksasa dan bahkan ada beberapa orang pencerita yang menyatakan Kbo Iwa adalah seorang raksasa juga merupakan logika legenda. Hal ini terjadi karena memang salah satu ciri legenda yang diciptakan 
oleh manusia pada zamannya sebagai salah satu cara untuk memahami peristiwa alam yang luar biasa yang pada saat itu belum dapat dijelaskan dengan logika ilmu pengetahuan pada masanya.

Hukum berikutnya adalah hukum kesatupaduan rencana cerita. Pada kisah Kbo Iwa yang muncul sejak awal adalah keinginan untuk melenyapkan Kbo Iwa karena tokoh ini sudah menghabiskan makanan baik itu makanan miliki orang tuanya maupun makanan yang dimiliki penduduk desa. Rencana untuk melenyapkan Kbo Iwa sudah dapat dirasakan pada sepertiga bagian awal kisah ini. Hal tersebut didukung dengan berbagai keterangan dan adegan yang memberikan gambaran kerakusan Kbo Iwa saat bersantap. Ini menunjukkan bahwa dalam kisah Kbo Iwa ini hanya ada satu rencana cerita. Ini juga menunjukkan bahwa sebuah legenda memiliki alur yang sederhana.

Hukum terakhir adalah hukum pemusatan pada tokoh utama. Hukum ini dengan jelas dapat diidentifikasi dalam kisah Kbo Iwa. Mulai dari awal cerita tokoh ini sudah menjadi pokok persoalan, bahkan sebelum tokoh Kbo Iwa dilahirkan. Orang tua Kbo Iwa yang kaya raya tetapi belum memiliki anak sangat berkeinginan untuk mendapatkan anak. Setelah mereka berdoa di Pura, dan mereka mendapatkan anak tersebut. Hal ini menunjukkan pentingnya atau pusat cerita memang ada pada tokoh Kbo Iwa sebagai tokoh utama. Hingga di akhir cerita, tokoh Kbo Iwa tetap menjadi pemusatan perhatian cerita. Hal ini menunjukkan bahwa struktur tokoh dalam sebuah legenda juga berbentuk struktur yang sederhana.

Berdasarkan analisis epik Axel Olrix terhadap kisah Kbo Iwa didapatkan hasil bahwa semua hukum tersebut muncul pada cerita kecuali dengan hukum kelima dan keenam yakni hukum keadaan yang berlawanan dan hukum anak kembar kerangka. Dari apa yang sudah dideskripsikan, didapatkan bahwa legenda Kbo Iwa yang berkaitan dengan asal usul terjadinya Danau Batur dibangun dengan struktur naratif yang sederhana, seperti hukum adanya satu rencana cerita dan pemusatan pada tokoh utama. Dengan kesederhanaan tersebut, sebuah cerita rakyat, secara khusus sebuah legenda, dapat dikisahkan turun temurun, dari seorang ibu ke anaknya.

\section{Tradisi Lisan di Sekitar Danau}

Batur sebagaimana sudah disebutkan sebelumnya disampaikan dipakai untuk nama danau, gunung, dan desa, serta yang terpenting adalah nama sebuah pura. Pura Ulun Danu Batur merupakan pura penting sebagai pura sad kahyangan jagat di Bali. Pura ini dinyatakan sebagai wujud rasa percaya kepada 
sang pencipta maha pemberi dan maha segalanya. ${ }^{24}$ Mengingat pentingnya peran pura ini bagi masyarakat Bali dan juga mengingat keramatnya pura ini salah satu konsep dalam masyarakat Hindu di Bali adalah konsep Yadnya yang salah satunya terwujud dalam upacara Bakthi Pakelem. Sebagaimana disampaikan oleh Sukada ${ }^{25}$ yadnya adalah salah satu penyangga bumi seperti yang disebutkan dalam Kitab Atarwa Weda. Pemeliharaan kehidupan di dunia ini berlangsung terus menerus sepanjang manusia itu ada. Upacara agama adalah salah satu bagian dari pancayadnya. Karena itu manusia berutang kepada Tuhan dan untuk menyampaikan rasa itu umat Hindu melaksanakan Dewa Yadnya sebagai Srada Bakthi/Yasa Karthi sekala lan niskala kepada Tuhan dan melakukan Buta Yadnya untuk memelihara semua ciptaaan Tuhan.

Salah satu upacara di sekitar danau Batur adalah Bakhti Pakelem. Sebagaimana sudah disebutkan bahwa Bakhti Pakelem termasuk salah satu bagian Bhuta Yadnya. Upacara ini dilaksanakan di dua tempat yakni di laut, danau, atau sungai dan di kepundang gunung. Bakhti Pakelem tidak dapat dilaksanakan di sembarang waktu, sembarang orang, dan sembarang tempat. Jika mengadakan Bakhti Pakelem di Danau Batur harus juga melaksanakan di puncak gunung Batur. Hal ini disebabkan puncak gunung Batur merupakan lingga dan Danau Batur merupakan yoni menuju keseimbangan Buana Agung, Buana Alit, dan Buana Sarira yang nantinya menuju Ajeg Bali. ${ }^{26}$

Upacara ini tidak dilaksanakan berdiri sendiri tetapi dilakukan dalam rangka Ngenteng Linggih atau Plodalan, dapat pula Mendak Toya bagi Organisasi Pertanian Subak di Bali. Untuk Pakelem di laut, danau, dan sungai dipersembahkan ke hadapan Sang Hyang Kala Sunia dan Pakelem di puncak Gunung Batur dipersembahkan ke hadapan Sang Hyang Kala Mertyu. Dua personifikasi energi yang hakikatnya tunggal yakni sebagai Siwa Kala Sang Maha Energi yang tak terjangkau Ida Pedanda Gede Kekeran Pemaron Griya Bancingan Munggu-Badung lewat Sukada. ${ }^{27}$

Dipercaya dari dua wilayah inilah kesejahteraan dunia terjaga. Dalam pandangan kosmologi Hindu, dua tempat ini senantiasa disucikan agar energi supra penghidup senantiasa terjaga. Gunung juga selalu dipuja karena diyakini di puncak gunung itulah roh leluhur bersemayam. Dalam teks tradisi Majapahit gunung adalah lingga acala (lingga=linggih, acala=tidak bergerak). Di kaki lingga

\footnotetext{
${ }^{24}$ Wayan Sukada, Karya Agung Tawur Agung Labuh Gentum, Mendak Toya, Tur Pakelem Ring Segara Danu Lan Gunung Batur (Danu Kerthi), (Desa Pekraman Batur: Segara Danu Pura Jati, 2009), h.2.

${ }^{25}$ Wayan Sukada, Karya Agung Tawur...,h. 11.

${ }^{26}$ Wayan Sukada, Karya Agung Tawur..., h.13.

${ }^{27}$ Wayan Sukada, Karya Agung Tawur..., h.14.
} 
itu, dibangun pura pemujaan dan aktivitas digerakkan. Bagi masyarakat gunung sejumlah pura di kaki gunung menjadi titik pusat pengintregasian sosial. ${ }^{28}$

\section{Simpulan}

Sebuah legenda diciptakan oleh manusia dengan tujuan untuk memahami peristiwa yang berkaitan dengan alam. Hal ini juga tampaknya dalam kisah Kbo Iwa yang merupakan legenda mengenai asal usul Danau Batur. Legenda itu tampaknya memang tercipta dalam usaha memahami peristiwa terjadinya danau. Hukum logika legenda sebagaimana diuraikan dalam salah satu hukum epik Olrix menyatakan bahwa sebuah legenda memiliki logikanya sendiri yang berbeda dengan logika ilmu pengetahuan. Logika tersebut berhubungan dengan hal-hal yang bersifat gaib. Apa yang muncul dan hadir dalam legenda Kbo Iwa seperti kesaktian sang tokoh yang dengan hanya menancapkan telunjuknya ke tanah akan memunculkan sumber air tampaknya menjadi titik tolak pemahaman terhadap terjadinya danau. Selain hukum logika legenda muncul juga beberapa hukum yang lain.

Secara khas nama "batur" sebagaimana sudah diuraikan mengacu kepada hal yang bersifat di atas atau sesuatu yang awal (kawitan) dan yang terpenting adalah sesuatu yang suci dan berhubungan dengan keberadaan sumber air kehidupan. Karena secara geografis, Danau Batur berhubungan dengan pemandian Tirta Empul yang dipercayai sebagai air suci. Danau Batur sendiri merupakan sumber air yang terbesar bagi pulau Bali. Hal yang menandai kesucian danau ini adalah adanya tradisi lisan Bhakti Pakelem. Tradisi ini mewajibkan masyarakat di pulau Bali untuk melaksanakannya secara rutin dalam waktu tertentu dengan tata cara tertentu yang tidak boleh terlewatkan. Bhakti Pakelem harus dilaksanakan di danau dan di gunung untuk menjaga keseimbangan kehidupan. Hal ini terjadi karena kata "batur" selain untuk menandai danau juga untuk menandai gunung dan menandai sebuah pura keramat yakni Pura Ulun Danu Batur.

Dengan demikian, dapat dinyatakan bahwa analisis terhadap asal usul danau Batur sebagaimana tidak dapat dilepaskan dari pemahaman terhadap posisi gunung dan juga pemahaman terhadap posisi pura yang ada di wilayah tersebut. Walaupun, sifat legenda sebagaimana legenda lainnya tidak berhubungan dengan hal-hal yang disucikan, kisah Kbo Iwa dapat dikatakan

\footnotetext{
${ }^{28}$ Wayan Sukada, Karya Agung Tawur...,h.15.
} 
menjadi latar belakang pemikiran pentingnya sumber air bagi kehidupan sebuah masyarakat.

\section{Daftar Pustaka}

Adhyanggono dkk. "Tradisi Cerita Lisan dalam Komunitas Tionghoa di Kawasan Pecinan Kota Semarang,” Laporan Penelitian. Semarang: Pusat Studi Urban Universitas Katolik Soegijapranata, 2005.

Alibasah, Margaret Muth. "Kbo Iwa” dalam Folk Tales from Bali and Lombok. Jakarta : Djambatan.

Danandjaja, James. Folklore Indonesia: Ilmu Gosip, Dongeng, dan lain-lain. Cetakan VII. Jakarta : Grafiti, 2007.

Sudikan, Setya Yuwana. Metode Penelitian Sastra Lisan. Cetakan Kedua. Lamongan: CV Pustaka Ilalang 2004.

Sukadia, Wayan. Karya Agung Tawur Agung Labuh Gentum, Mendak Toya, Tur Pakelem Ring Segara Danu Lan Gunung Batur (Danu Kerthi). Desa Pekraman Batur: Segara Danu Pura Jati, 2009.

Septiandari, Sekar. "Kebo Iwa" dalam Seri Cerita Rakyat Bali. Jakarta : Karisma Publishing Group, 2010.

Suparta, I Made. "Analisis Tokoh Kebo Iwa dalam Kakawin Kebo Tarunantaka”. Laporan Penelitian. Jakarta: Fakultas Sastra Universitas Indonesia, 1994/1995.

Sutarto. Legenda Kasada dan Karo Orang Tengger Lumajang. Jakarta : Fakultas Sastra Universitas Indonesia, 1997.

Turnbull, Joanna. Oxford Advances Learner's Dictionary. Eighth Edition. Oxford : Oxford University Press, 2000.

Yusuf, Muri. Metode Penelitian Kuantitatif, Kualitatif \& Penelitian Gabungan. Jakarta : Prenadamedia Group, 2014.

\section{Sumber Internet}

Sumber foto: http://www.beritabali.com/index.php/page/berita/gyr/detail/31 /07/2011/Kebo-Iwakoma-Panglima-Militer-Bali-Pada-Awal-Abad-kemin14-/201107020237 
Sumber foto: http://www.kidnesia.com/Kidnesia2014/Indonesiaku/Jalan-Jalan/ Menjaga-Geopark-Kaldera-Gunung-Batur

"Mata Air Suci di Pura Tirta Empul" dalam http://id.balibalibeach.com/pura/p ura-tirta-e mpul-mata-air-suci/feed/ diunduh 7 Maret 2011.

"Subak dari Bali ditetapkan sebagai warisan dunia" dalam http://m.nationalgeographic.co.id/berita/2012/06/subak-dari-bali-ditetapkansebagai-warisan-dunia diunduh 7 Maret 2013

"Koneksitas Danau Batur Tirta Empul” dalam http://stitidharma.org/ koneksitas-danau-batur-tirta-empul/diunduh 10 Maret 2013

"Kami Penjaga Alam Danau Batur" dalam http://tanahair.kompas.com/read /2012/09/18/1656278/Kami.Penjaga.Alam.Danau.Batur diunduh 12 Maret 2013. 